\title{
Naturalizm a spirytualizm i problem jedności wiedzy o człowieku. Stanowisko Roberta Spaemanna
}

DOI: http://dx.doi.org/10.12775/RF.2019.044

\section{Wprowadzenie}

Współczesne debaty na temat praw człowieka, technologii genetycznych, ochrony ludzkich embrionów albo kwestii związanych z początkiem i końcem życia ludzkiego są naznaczone głęboką ambiwalencją - podkreśla niedawno zmarły Robert Spaemann, jeden z najwybitniejszych współczesnych myślicieli niemieckich ${ }^{1}$. Jego zdaniem należy widzieć $\mathrm{w}$ tym wyraz fundamentalnego dualizmu w mentalności naszej epoki. Chodzi o dualizm, który ujawnia się w przeciwstawnych sobie stanowiskach - naturalizmie ${ }^{2}$ i spirytualizmie ${ }^{3}$. Ażeby zrozumieć wszelki du-

1 Robert Spaemann, „Die zwei Interessen der Vernunft”, w: Robert Spaemann, Über Gott und die Welt (Stuttgart: Klett-Cotta, 2012), 322.

2 Naturalizm to pogląd, który w rozumieniu Spaemanna redukuje człowieka do poziomu czysto biologicznego. Odcina go też od transcendencji.

${ }^{3}$ Spirytualizm w teorii człowieka w postaci skrajnej sprowadza człowieka do elementu duchowego, gdyż ciało, w świetle tego stanowiska, nie współtworzy istoty człowieka albo stanowi jego udrękę (platonizm). Spirytualizm umiarkowany głosi zaś, iż człowieka współstanowi obok ciała niematerialna dusza. Zob. Antoni B. Stępień, Wstęp do filozofii (Lublin: Towarzystwo Naukowe KUL, 1995), 399. Spaemann poddaje krytyce spirytualizm w sensie platońskim, zgodnie z którym istotę człowieka 
alizm (i jakąś biegunowość), nie wolno być w niego uwikłanym, lecz przyjmować punkt widzenia świadczący o dystansie i pozostawaniu na zewnątrz takiego stanowiska lub jakoś ponad nim. W przeciwnym razie dualizm pogrąża się w dialektyce, w której każde stanowisko, nawet w sposób nieświadomy i niedobrowolnie, przeistacza się w orientację przeciwną. W filozofii pojawiają się próby zrozumienia owej dialektyki. Jest to intencją chociażby filozofii Hegla. Jego filozofia nie chce być filozofią dialektyczna, lecz taką, która tę dialektykę, w jakiej wikła się każdy skończony i ograniczony punkt widzenia, odkrywa i rozumie, i chce ją przezwyciężyćt.

Już z powyższych względów nietrudno dostrzec doniosłość analiz filozoficznych na temat naturalizmu i spirytualizmu, jakie zostaną podjęte w tym artykule. Przedstawiają one ujęcie wspomnianego Roberta Spaemanna. Od razu wszakże trzeba zaznaczyć, że analizy te nie ograniczają się tylko do charakterystyki dwóch interesujących nas tu szczególnie stanowisk, chociaż owszem, ta problematyka zostanie zaprezentowana $\mathrm{w}$ niniejszych rozważaniach najszerzej. Zapoznanie się z nią jest nader ważne, gdyż pozwala dostrzec, jak bardzo naturalizm i spirytualizm naznaczają i określają treść oraz charakter naszej wiedzy o rzeczywistości, a szczególnie o człowieku. Pomagają też uchwycić ambiwalencję, jaka ujawnia się $\mathrm{w}$ treści analiz podejmowanych na ten temat tak od strony naukowej, jak i filozoficznej.

Przy opisie drugiego zagadnienia podjęta będzie próba odpowiedzi na pytanie, czy w przypadku redukcjonistycznej wiedzy o rzeczywistości, a zwłaszcza o człowieku (jaką nam oferują te stanowiska) można mówić o jej jedności. Niezależnie od tego zostanie postawiony problem jedności dwóch sposobów poznania bytu ludzkiego: poznania przyrodniczego i poznania metafizycznego.

\section{Naturalizm i spirytualizm w nauce i w filozofii}

Światopoglądem Hitlera był naukowy naturalizm*

Co kryje się pod pojęciem dialektyki spirytualizmu i naturalizmu, powinno nam uzmysłowić kilka przytoczonych poniżej przykładów.

definiuje dusza. Ciało to narzędzie, które ona wykorzystuje. Nie wchodzi ono do definicji człowieka.

"Robert Spaemann, „Nienawiść Sarastra”, w: Robert Spaemann, Granice. O etycznym wymiarze działania, przeł. Jarosław Merecki (Warszawa: Oficyna Naukowa, 2006), 267.

4 Tamże, s. 322-323. 
Mamy oto powszechnie do czynienia z naturalistycznym rozumieniem poznania, które dzisiaj opiera się na teorii ewolucji i neurobiologii - akcentuje Spaemann ${ }^{5}$. Naturalizm interpretuje bowiem poznanie jako pewną formę dopasowywania się organizmu do swego otoczenia (środowiska), i to nie tylko $\mathrm{w}$ takim sensie, że nasze poznanie ułatwia nam przetrwanie i $\mathrm{w}$ ten sposób zapewnia nam pewną przewagę $\mathrm{w}$ procesie (Spiel) selekcji. Stanowisko naturalistyczne postrzega poznanie $\mathrm{w}$ sensie jeszcze bardziej radykalnym. Według niego stany ludzkiego organizmu (który sam siebie traktuje jako pojmowanie tego, co jest i istnieje) w rzeczywistości są tylko pewnym efektem/rezultatem w procesie jego dopasowywania się do środowiska.

Zdaniem Spaemanna z podejściem naturalistycznym współbrzmi teza Davida Hume'a: „Nigdy nie wychodzimy nawet o krok poza samych siebie". Transcendencja samego siebie (własnego "ja”) jest iluzją Nie mamy bowiem dostępu do świata realnych rzeczy, istniejących na zewnętrz nas ${ }^{7}$. To naturalistyczne podejście rości sobie jednak prawo do prawdy w tradycyjnym sensie tego słowa. Każe ono sądzić, że przedmiot, który się bada, istnieje realnie. Według niemieckiego myśliciela w świetle założeń naturalizmu można bowiem powiedzieć, jakoś w zgodzie ze stwierdzeniem Etienne'a Gilsona, że „każdy jest realistą w odniesieniu do czegoś (czegokolwiek)". Neurolodzy na przykład są realistami odnośnie do mózgu ${ }^{8}$. Gdzie tu jednak w tym wszystkim jest podmiot poznania? ${ }^{9}$

5 Spaemann, „,Die zwei Interessen der Vernunft”, 322-323.

6 Stwierdzenie: "Nigdy nie wychodzimy nawet o krok poza samych siebie" znaczy, że my po prostu nie znamy rzeczywistości, lecz tylko wrażenia zmysłowe i ich kopie (idee). W gruncie rzeczy odnosimy się zawsze tylko do wrażeń, a nigdy do samej rzeczywistości (np. widzę jabłko, ale nie mogę stwierdzić, czy odpowiada mu realny byt). Pewne jest, że istnieje „ja”, które posiada wrażenia i idee. Na pytanie: „Kim właściwie jestem?” nie można jednak odpowiedzieć w ten sposób, że istnieje jakieś „,ja” substancjalne (skrajny empiryzm).

7 Robert Spaemann, Osoby. O różnicy między czymś a kimś, przeł. Jarosław Merecki (Warszawa: Oficyna Naukowa, 2001), 179.

${ }^{8}$ Są nimi w tym sensie, gdy mówią na przykład, jaką mózg ma strukturę i jak funkcjonuje. Przestaliby jednak być realistami, gdyby postawili tezę, że mózg jest źródłem myślenia, a nie jego narzędziem.

9 Istnieje jakby wiedza ponad nami, wspólna dla wielu podmiotów. Mamy wspólny podmiot wiedzy, nie ,ja" indywidualne, ale ponadindywidualną strukturę. Istnieje coś, co jest podmiotem wiedzy, podobnie jak u Arabów (Awicenna), którzy mówili o wspólnym umyśle, a człowiek w nim tylko partycypuje. Czymś takim jest teraz nauka, coś ponadjednostkowego, w czym mamy udział, ale raczej jako jej instrumenty. Świadczy to jednak o tym, że to nie my poznajemy, ale te wszystkie nauki, rozumiane jako jedna dziedzina wiedzy. Jawi się tu problem: jeśli jest to ponad nami, gdzie tedy egzystuje? Pojawia się tu jak gdyby duch zbiorowy, wspólny intelekt upostaciowiony w nauce i wiedzy. My poprzez swoje poznanie współtworzymy tego 
Nowym transcendentalnym podmiotem stała się dzisiaj nauka podkreśla Spaemann ${ }^{10}$. W holistycznej interpretacji Willarda Van Ormana Quine’a nauka jest totalnością, która nie dopuszcza niczego poza samą sobą. Jest ona jak zakrzywiona przestrzeń: można iść prosto przed siebie, nie napotykając na granice, i na końcu dojść do punktu wyjścia ${ }^{11}$. Nauka składa się z partykularnych gałęzi wiedzy (poszczególnych nauk), z których każda jawi się dla drugiej jako, można rzec, dziedzina zewnętrzna. Każdej z nich wszelka teoria pozostawia jakieś nierozwiązane kwestie. Przedmiotem materialnym tej totalnej nauki jest tylko przedmiot, a zatem bezładna materia. Nauka sama zajęła miejsce, które wcześniej było zarezerwowane dla podmiotu transcendentalnego. Nie przynależy ona już do świata ${ }^{12}$. Samo rozumienie poznania, podobnie jak i prawdy, ma charakter normatywny ${ }^{13}$, a nie deskryptywny.

Niestety w takiej sytuacji, jak dodaje Spaemann, kwestia, czy określony stan świadomości jest poznaniem, czy nie, nie zależy od kompletnej obiektywnej informacji o nim. Błędy jako stany subiektywne nie odróżniają się od prawdziwych przeświadczeń. Słowo "poznanie" oznacza tylko prawdziwe i dobrze uzasadnione przeświadczenia ${ }^{14}$. Znaczy to, że pojęcie „poznanie” implikuje roszczenie do słuszności i owa słuszność jest głównym przedmiotem epistemologii. Na poziomie subiektywnym, jako przeświadczeniu i jako stanie mózgu, nie ma różnicy między poznaniem prawdziwym i błędnym.

Filozoficznie błędne rozumowanie, które leży u podstaw naturalistycznej epistemologii, można - w przeświadczeniu Spaemanna - dobrze uchwycić u Konrada Lorenza ${ }^{15}$. Jego książkę Die Rückseite des Spiegels poprzedził artykuł, który ukazał się w 1947 roku. Lorenz podaje w nim ewolucyjne wyjaśnienie kantowskich form a priori oglądu (form naoczności). Formy te mogą być, wedle Lorenza, rozumiane jako rezul-

ducha i ten intelekt oraz sprawiamy, że nauka i wiedza jakby się substancjalizowały, materializowały i stawały wspólnym podmiotem.

10 Spaemann, „Die zwei Interessen der Vernunft”, 323.

11 Dla takiej nauki nic poza nią nie istnieje z wyjątkiem pewnej całości (totalność), pozostającej bez związku z realnością. Jest ona niczym budowla wisząca w powietrzu. W systemach zamkniętych (logicznych) odkrywa się różne rzeczy, by w końcu wrócić do wyjściowych założeń (aksjomatów). Tak może się dziać bez końca.

12 Nauka zatem oderwała się od rzeczywistości i funkcjonuje we własnym świecie jako tylko teoretycznym bez odniesienia do realności. Prawda jako taka praktycznie zginęła i liczy się wyłącznie słuszność (jako subiektywne przekonanie o niej), koherencja, zgodność z całością itd.

13 Skoro poznanie jest oderwane od obiektywnej rzeczywistości i nie ma z nią nic wspólnego, to wszelkie sądy na jej temat są normatywne, czyli nic nie opisują (nie mówia, jak jest, ponieważ tego, co jest, nie ma i zamiast tego jest teoria). Sądy te tylko pokazują jakąś wewnętrzną koherencję, zgodność albo niezgodność z całością.

${ }^{14}$ Spaemann, „Die zwei Interessen der Vernunft”, 323.

15 Tamże. 
taty procesu dostosowania organizmów. Chodzi o standardy (Schemata), które pozwalają w organizmie na to, by w korzystny sposób reagować na otoczenie. Zdaniem Spaemanna interpretacja ta myli kantowskie formy a priori ${ }^{16} \mathrm{z}$ wewnętrznymi dyspozycjami, to znaczy z czymś, co empirycznie da się stwierdzić. Interpretacja ta jednak nie odpowiada zamysłowi Kanta ${ }^{17}$. Kantowi chodzi nie o psychiczne dane, ponieważ sama psychologia jest możliwa tylko dzięki tym formom a priori. Kantowskie a priori nie jest pojęciem psychologicznym, lecz ściśle epistemologicznym $^{18}$. Poznanie a priori jest przeświadczeniem lub stwierdzeniem, które może być usprawiedliwione, to znaczy jego prawdziwość jest rozpoznawalna bez odniesienia do zmysłowego doświadczenia. Podmiotem takiego poznania ostatecznie nie może być empiryczny człowiek, żadne psychologiczne "ego", ponieważ ono podlega uwarunkowaniom form a priori wewnętrznego oglądu. Jeśli jednak, jak konstatuje Spaemann, w naturalistycznej teorii poznania transcendentalne "ego"19 jest zastąpione przez empiryczny ludzki podmiot, a formy a priori przez wrodzone jakości podmiotu, wtedy powraca niezauważalnie transcendentalne „ja”, a mianowicie w formie abstrakcyjnego podmiotu zwanego nauką. Podmiot ten (nauka) w rzeczywistości nie jest poznaniem i wiedzą o konkretnych osobach, lecz anonimowym i abstrakcyjnym procesem, który generuje u konkretnych podmiotów hipotetyczną wiedzę ${ }^{20}$.

Współczesna nauka, zdaniem Spaemanna, jest per definitionem materialistyczna. Jeden z jej teoretyków, Daniel Dennett, pisze, że nie zamierza prowadzić debaty o materialistycznym monizmie. Stanowisko to jest dla niego warunkiem a priori każdego naukowego badania ${ }^{21}$ i dlatego należy go bronić, podobnie jak broni się dogmatów religii22. Tym samym jednak nauka, według monachijskiego myśliciela, staje się instancją czysto spirytualną i pozaświatową. Jest to zjawisko, które - zda-

16 Formy a priori to formy naoczności: czasu i przestrzeni.

17 Spaemann, „Die zwei Interessen der Vernunft”, 324.

18 Kantowskie a priori jest pojęciem epistemologicznym, czyli związanym z warunkami możliwości poznania w nauce.

19 Transcendentalny podmiot to struktura, która nie ma charakteru osobowego, nie jest indywidualnym „ja”", lecz „ja” w ogóle, czystą świadomością wyrażaną w zdaniu: ,ja jestem i myślę". Jest to warunek niezbędny wszelkiego poznania. Tego „ja" doświadczam nie bezpośrednio, ale pośrednio poprzez skutki. Wiemy, co ono robi, jakie skutki powoduje i dzięki temu rozpoznajemy, jakie ono jest.

20 Spaemann, „Die zwei Interessen der Vernunft”, 325.

${ }^{21}$ Jest to warunek sine qua non, bez którego nie ma naukowego badania. Stanowisko materialistyczne jest warunkiem a priori, czyli takim, który zakładamy uprzednio bez odwoływania się do jakiegokolwiek doświadczenia, ponieważ tylko dzięki temu można mówić o naukowym badaniu.

${ }^{22}$ Dennet z góry wyjaśnia, że pryncypialnie nie akceptuje żadnych argumentów przeciw naturalistycznemu redukcjonizmowi. Robert Spaemann, Das unsterbbliche Gerücht (Stuttgart: Klett-Cotta, 2007), 48. 
niem Spaemanna - można nazwać przeobrażeniem naturalizmu w spirytualizm ${ }^{23}$. Oczywiście niemiecki filozof przywołuje tutaj spirytualizm nie we właściwym (przyjętym powszechnie) jego znaczeniu. W takim wypadku jest to stanowisko przeciwstawne materializmowi, które głosi, że każdy byt lub niektóre jego rodzaje są natury duchowej ${ }^{24}$. Niemiecki myśliciel określa myślową orientację Dennetta jako spirytualistyczna, ale w specyficznym dla niej sensie. Naturalista amerykański formułuje ją bowiem nie na podstawie zweryfikowanych informacji płynących z doświadczenia, lecz takich danych, które duch ludzki dowolnie kreuje (wręcz wymyśla). Są one raczej wynikiem jego decyzji. Dlatego można powiedzieć, że u Dennetta, zdaniem Spaemanna, dochodzi do głosu decyzjonizm $^{25}$.

\section{Naturalizm i spirytualizm w refleksji antropologicznej i moralnej}

Dialektykę analogiczną do tej, którą Spaemann wskazuje w obszarze nauki i filozofii, należy postrzegać, w jego przeświadczeniu, na płaszczyźnie rozumienia bytu ludzkiego ${ }^{26}$. Mamy tu do czynienia z naturalistyczna, to znaczy materialistyczna, antropologia, dla której człowiek jest tylko naturą (ma tylko wymiar biologiczny) i wszelkie ludzkie działania są definiowane przez ich funkcje naturalne, to znaczy biologiczne.

Moralność jest w takiej koncepcji antropologicznej wyłącznie funkcją przetrwania gatunku. Wprawdzie dla niektórych jej reprezentantów, od kiedy tylko posługują się językiem normatywnym, słowo „biologizm" staje się nagle pejoratywne. Inni bowiem autorzy, którzy uprawiają w antropologii biologizm, i to tak dalece, jak to tylko jest możliwe, odrzucają wszelką normatywność prawa naturalnego.

Oto, zdaniem Spaemanna, Peter Singer deklaruje, z jednej strony, materialistyczną antropologię. Według bowiem utylitarystycznego etyka sama przynależność do gatunku ludzkiego nie implikuje godności. $Z$ tego względu wartość dorosłej świni jest, w jego opinii, wyższa niż jednorocznego dziecka. $Z$ drugiej jednak strony żąda on od nas moralnej postawy, przekraczającej możliwości każdej skończonej istoty i jej zdolności wchodzenia w relacje bliższe i dalsze. Ma ona być równa Bogu.

23 Spaemann, „Die zwei Interessen der Vernunft”, 325.

${ }^{24}$ Stępień, Wstęp do filozofii, 399.

25 Decyzjonizm, według Spaemanna, to raczej postawa, która każe nam sądzić, że to my musimy rozstrzygać. Rozstrzygnięcia jednak nie mają ostatecznego uzasadnienia. Chodzi w nich bowiem o sam imperatyw ich podejmowania. (Na podstawie rozmowy autora artykułu z Robertem Spaemannem w listopadzie 2011 roku).

26 Spaemann, „Die zwei Interessen der Vernunft”, 325-326. 
Singer zakazuje wszelkiej stronniczości względem krewnych i członków rodziny ludzkiej, domagając się totalnej bezinteresowności jako jedynej możliwej postawy moralnej. Taka teoria nie ma jednak uzasadnienia, skoro w przeświadczeniu Singera człowiek niczym nie różni się od zwierząt. Tak czy inaczej, proklamuje on „antynaturalistyczny” spirytualizm - wyjaśnia Spaemann ${ }^{27}$. Moralność staje się w jego wizji niezależna od wszelkiego powiązania $\mathrm{z}$ tym, co naturalne, i wyemancypowuje się z każdego związku z ludzką naturą. O godności osobowej rozstrzygają bowiem jedynie określone mentalne uzdolnienia: samostanowienie, samoświadomość. Natura fizyczna i konstytucja cielesna w niczym jej nie współtworzą i dlatego nie mają w tej godności żadnego udziału.

Od kilku dziesięcioleci, zdaniem Spaemanna, wytworzyła się fundamentalna, a niekiedy wręcz fundamentalistyczna reakcja na kartezjański dualizm, postulujący traktowanie przyrody jako obiektu (przedmiotu) nasilającej się nad nią dominacji ${ }^{28}$. Reakcję tę należy odczytywać jako wyraz zrozumienia, że środki (narzędzia) panowania nad naturą są jednocześnie zawsze środkami (narzędziami) dominacji człowieka nad człowiekiem. Pod wpływem ruchu ekologicznego (z jej naturalistyczną wizją przyrody) coraz lepiej zdajemy sobie sprawę z fatalnych skutków ubocznych ${ }^{29}$ podporządkowania przyrody ludzkiemu planowaniu, którego pole oddziaływania ciągle się poszerza. Zaczyna się zatem rozumieć, że każda próba uporania się z takimi skutkami tą drogą (czyli w postaci nakreślenia nowych planów) powoduje coraz większe niepożądane efekty uboczne, co bardzo dobrze, według monachijskiego myśliciela, pokazał socjolog Friedrich Tenbruck ${ }^{30}$. Zachodzi tu ambiwalencja $\mathrm{w}$ tym sensie, że człowiek, z jednej strony, chciałby usunąć skutki uboczne, ale one paradoksalnie się nasilają ponieważ podchodzi do przyrody z zamiarem jej zdominowania.

Na tę samą ambiwalencję, zdaniem Spaemanna, cierpi często ruch ekologiczny. Według bowiem wielu jego luminarzy człowiek musi zrezygnować z roszczenia sobie prawa do uprzywilejowanego i wyjątkowego miejsca w przyrodzie. Ich zdaniem powinien on rozumieć, że nie może stanowić centrum świata, lecz ma być jedną z istot naturalnych (naturalizm w pojmowaniu człowieka) pośród innych. (I ma się on do nich odnosić z tym samym respektem, jakiego wymaga dla siebie).

27 Spaemann, „Die zwei Interessen der Vernunft”, 326.

${ }_{28}$ Robert Spaemann, „Wirklichkeit als Anthropomorphismus”, w: Robert Spaemann, Schritte über uns hinaus Gesammelte Reden und Aufsätze II (Stuttgart: Klett-Cotta, 2007), 200-202.

${ }^{29}$ Uboczne skutki to zwrotne oddziaływanie przyrody na człowieka, które okazuje się dla niego szkodliwe.

30 Spaemann, „Die zwei Interessen der Vernunft”, 327. 
Żądanie to jednak jest, jak słusznie zauważa Spaemann, sprzeczne samo w sobie ${ }^{31}$. Każda naturalna istota jest dla siebie samej centrum. Świat jawi się dla niej tylko jako otoczenie. Dla kota mysz to wyłącznie zdobycz. Kot nie wie, czym jest dla myszy. Tymczasem człowiek jest kimś wyjątkowym. Zajmuje on, jak trafnie według Spaemanna wyraził się Helmut Plessner, pozycję ekscentryczną. Człowiek ma, by tak rzec, spojrzenie z dystansu (view from nowhere) i wie, że jestestwa same w sobie, czyli o strukturze podmiotowej, są czymś innym niż tym, czym są dla nas ${ }^{32}$. Tylko na gruncie swej całkowicie wyjątkowej sytuacji człowiek potrafi respektować inne naturalne istoty. Zlecony mu biblijny mandat, uprawniający do panowania nad przyroda, żąda, by zajmował się swoimi poddanymi jak przyjazny pan. Nie wyklucza to jednak, aby ubocznie korzystał z nich dla własnych interesów. Człowiek sam jest zwierzęciem, które żyje w dużym stopniu z eksploatacji swego otoczenia. Na gruncie swych specyficznych jakości może on nieograniczenie poszerzać obszar swego panowania. Niemniej tylko z ich mocą potrafi postawić samemu sobie granice. Kto neguje tę uprzywilejowaną pozycję człowieka, podważa możliwość dobrowolnego samoograniczania się nas jako ludzi - trafnie konkluduje wybitny myśliciel ${ }^{33}$.

Dodajmy, że ruch ekologiczny ma charakter naturalistyczny z innego jeszcze, ale istotnego powodu. Wielu jego reprezentantów motywuje ochronę przyrody nie tym, że jest ona stworzeniem Bożym, lecz z tej racji, że przyroda jako natura ma wartość samą w sobie (stanowisko biocentryczne).

Twierdzić, że człowiek zajmuje uprzywilejowaną pozycję na gruncie swej ekscentrycznej pozycji, nie oznacza, iż popada się w spirytualizm podkreśla Spaemann ${ }^{34}$. Człowiek jest istotą duchową i jednocześnie naturalna, posiadającą ciało. Owszem, może się on, jeśli chce, wyemancypować ze swej natury. Przez to jednak nie stanie się Bogiem. Pozostanie wtedy wyobcowaną wobec siebie samego istota, która radykalnie może się wyemancypować tylko w wyniku samobójstwa. Conditio humana nie jest ani czysto biologiczna, ani czysto duchowa. Taka prawda o bycie ludzkim jest nie do pogodzenia z dialektyką spirytualizmu i naturalizmu.

31 Tamże.

32 Spaemann, Osoby. O różnicy między czymś a kimś, 20-21; Helmut Plessner, „Die Stufen des Organischen und der Mensch. Einleitung in die philosophische Anthropologie”, w: Gesammelte Schriften, Bd. IV (Frankfurt am Main: Suhrkamp, 1981), 360.

33 Spaemann, „Die zwei Interessen der Vernunft”, 328.

34 Tamże. 
Niestety, te przeciwstawne sobie stanowiska są zdaniem niemieckiego myśliciela ciągle nieświadomie reprodukowane ${ }^{35}$. Dzieje się tak również w przypadku treści praw człowieka.

Według naturalistów nie ma podstaw, by mówić o tych prawach. Spirytualiści ich nie wykluczaja, lecz zawężają do świata osób. Wychodząc z założenia, że człowiek jest istotą dualistyczna, traktują jako rzeczywiste w nim tylko to, co duchowe i świadome. Bycie osobą zakłada $\mathrm{w}$ ich mniemaniu, że dysponuje się rozwiniętymi właściwościami personalnymi, przede wszystkim samoświadomością. Nie przysługują nam więc prawa człowieka na podstawie samego faktu bycia człowiekiem. Może je bowiem posiadać tylko ktoś, kto jest osobą. Prawa człowieka jednak w ich źródłowym znaczeniu (św. Tomasz z Akwinu, Kant) obejmują wszystkich ludzi, niezależnie od tego, czy rozwinęła się u nich samoświadomość, czy też jeszcze nie. Każdy bowiem człowiek w rozumieniu klasycznym jest osobą. Nie można zatem tych praw odmówić niemowlętom, dzieciom jeszcze nienarodzonym czy ludziom upośledzonym psychicznie. Przeciwnie sądzą spirytualiści, których zdaniem podmiotem praw mogą być jedynie ci, którzy znajdują się w określonej fazie rozwoju, wskazującej, że są samoświadomi.

Jak podkreślono, naturalizm i spirytualizm dochodzą do głosu w kontekście praw człowieka. Pozwala to lepiej zrozumieć, dlaczego w prawodawstwie ujawnia się ambiwalencja, o jakiej świadczy sposób postrzegania podstawowego prawa każdego człowieka, a mianowicie prawa do życia i ściśle z nim związanej kwestii godności.

W konstytucji niemieckiej godność człowieka jest pojmowana jako wartość nienaruszalna. Respekt dla niej nie jest ograniczany przez jakiekolwiek zastrzeżenia prawne. Nieograniczone jest również prawo do życia, o ile dotyczy każdej ludzkiej istoty, począwszy od jej poczęcia. Ostatecznie nie jest ono jednak tak absolutne, jak nienaruszalność godności człowieka. Jest ono postrzegane jako konsekwencja ludzkiej godności, ale nie jako wartość z nią równorzędna. W tym właśnie względzie wolno mówić o sprzeczności rozstrzygnięć jurysdykcyjnych - słusznie konstatuje Spaemann ${ }^{36}$. Jeśli bowiem stosownie do ich orzeczeń godność człowieka stanowi jego najwyższe prawo, to musiałoby z nich wynikać, że życie ludzkie ma ten sam status. $W$ tej jednak kwestii prawo nie rozstrzyga w ten sposób. Dopuszcza bowiem aborcję, mimo iż uznaje ją za niezgodną z tym prawem. Niewątpliwie więc okazuje niekonsekwencję $\varepsilon^{37}$.

35 Tamże.

36 Tamże, 328-329.

37 Robert Spaemann, „Kto i za co jest odpowiedzialny”, w: Robert Spaemann, Granice. O etycznym wymiarze działania, przeł. Jarosław Merecki (Warszawa: Oficyna Naukowa, 2006), 415. 
Naturalizm i spirytualizm zadomowił się także we współczesnej mentalności ludzi. Ta zaś wyraźnie ujawnia się m.in. w traktowaniu własnego ciała. Trzeba tu odnotować znamienny paradoks. Mentalność ta, jak podkreśla Spaemann, chętnie jest pojmowana materialistycznie, ale jest raczej spirytualistyczna ${ }^{38}$. Dla niej własne ciało to nie wyraz ducha i medium osobowej miłości. Do takiego ciała odnosi się bowiem jak do przedmiotu i narzędzia służącego podmiotowi do uzyskiwania egoistycznej przyjemności. $\mathrm{W}$ takim podejściu do ciała mentalność ta ujawnia nie tylko swą hedonistyczną orientację. Ciało $\mathrm{w}$ takim podejściu jest zupełnie pozbawione wymiaru personalnego, zostaje zredukowane do poziomu czystej materii. Można je używać tak jak inne materialne przedmioty. Spirytualizm ujawnia się tutaj szczególnie w nastawieniu, zgodnie z którym ciało nie jest częścią naszej osoby i nie przynależy do niej. Jawi się jako coś, co usprawiedliwia instrumentalne jej traktowanie. Tutaj potwierdza się trafność osądu Spaemanna, że dzisiejszy naturalizm ma rzeczywiście przesłanki spirytualistyczne. Dla tej bowiem mentalności nasza osoba to duchowy podmiot, wobec którego ciało stanowi rzeczywistość zewnętrzną i całkowicie obcą. Dlatego wolno nam uczynić z nim, cokolwiek chcemy, tak jak postępujemy ze wszelkimi innymi rzeczami, które do nas nie należą. Jest to więc pogląd w pewnym sensie właściwy dla Platona, skoro odmawia ciału współtworzenia harmonijnej jedności w człowieku (wyklucza jedność duszy i ciała).

W fascynujący sposób tę problematykę przedstawił, według Spaemanna, Walker Percy w powieści Love in the Ruins. Jej bohater, amerykański psychiatra Thomas More, potomek świętego o tym samym imieniu i nazwisku, mówi w tym kontekście o angelizmie. Rozumie przez to tę własność człowieka, która pozwala mu na abstrahowanie od siebie i na życie niejako poza własnym ciałem. Niestety prowadzi to do degeneracji pożądań. W tej sytuacji Kościół katolicki, który chyba jako jedyny broni dziś konsekwentnie osobowego wymiaru cielesności i cielesnego wymiaru osoby ludzkiej, ma trudności z wyjaśnieniem swojego stanowiska, jakkolwiek jest ono klasyczne i uniwersalne. Kiedy Kościół sprzeciwił się instrumentalnemu oddzielaniu aktu seksualnego od poczęcia dziecka przez interwencje chemiczne $w$ ciele kobiety, opinia publiczna zarzuciła mu wrogość wobec rozkoszy seksualnej i obsesję w kwestii produkcji dzieci. Dzisiaj natomiast fakt, że Kościół dezaprobuje oderwane od rozkoszy seksualnej „poczynanie” dzieci w probówce, pokazuje, że chodzi o coś innego: o osobowy kontekst. Zdaniem Spaemanna spo-

\footnotetext{
38 Tamże, 414.
} 
śród wielkich intelektualistów ostatnich dziesięcioleci dobrze pojął ten kontekst jedynie Max Horkheimer ${ }^{39}$.

\section{Problem jedności wiedzy o człowieku}

Pod pojęciem jedności wiedzy o człowieku można rozumieć spójność (niesprzeczność) tez i treści pochodzących z różnych i niezależnych źródeł (empirycznych, metafizycznych, fenomenologicznych) na temat tego, kim on jest. Redukcjonistyczne stanowiska naturalizmu i spirytualizmu pretendują ze swego punktu widzenia do miana kreatorów wizji jedności wiedzy o człowieku. Wszak formułują tezy o bycie ludzkim przeciwstawne sobie i wzajemnie się wykluczające (dlatego próba ich połączenia nie wchodzi w rachubę). Innymi słowy, antropologiczne tezy tych stanowisk nie dają się ze sobą pogodzić tak, by tworzyły jedną spójną całość (jedność wiedzy o człowieku). Naturalizm neguje istnienie w człowieku duszy jako samoistniejącego elementu bytowego, a spirytualizm w swej skrajnej postaci zaprzecza, by cielesność miała jakiekolwiek znaczenie dla samorozumienia się nas jako ludzi. Tak czy inaczej, zarówno jedno, jak i drugie stanowisko jako skrajna, jednostronna i selektywna antropologiczna wizja nie tłumaczy w pełni faktu bycia człowiekiem (widzianego tak od wewnątrz, jak i od zewnątrz) ${ }^{40}$.

Dlatego trzeba poszukiwać bardziej wyważonego, nakreślonego w szerszej perspektywie stanowiska w odniesieniu do problemu jedności wiedzy o człowieku, które nie tylko nie artykułowałoby sprzecznych tez o bycie ludzkim, ale prezentowałoby także adekwatny jego obraz. Znajdujemy go w Spaemannowskiej refleksji antropologicznej.

Niemiecki myśliciel wskazuje bowiem możliwość jedności dwóch sposobów (perspektyw) poznania człowieka: przyrodniczego i metafizycznego. Równolegle z tym akcentuje, na jakiej zasadzie staje się to możliwe. Nie ulega dla niego wątpliwości, że te dwa sposoby muszą się wzajemnie uzupełniać, aby powstał całościowy, odpowiedni obraz człowieka. Jak bowiem podkreśla ten wybitny myśliciel, gdybyśmy patrzyli na człowieka tylko z punktu widzenia biologii, nieuchronnie musielibyśmy mówić o czymś, co jest daleko mniejsze niż człowiek ${ }^{41}$. Przy ta-

${ }^{39}$ Horkheimer dał temu wyraz przed około pięćdziesięciu laty, gdy pisał, że za pigułkę antykoncepcyjną musi się zapłacić śmiercią miłości między mężczyzną i kobietą. Max Horkheimer, Die Sehnsucht nach ganz Anderen (Hamburg: Furche-Verlag, 1970), 75.

${ }^{40}$ Wprawdzie w swym przeświadczeniu zarówno naturaliści, jak i spirytualiści artykułują adekwatną wiedzę o bycie ludzkim, faktycznie jednak popełniają błąd jednostronności, redukując prawdę o nim bądź do sfery fizycznej, bądź duchowej.

${ }^{41}$ Robert Spaemann, „Über den Begriff einer Natur des Menschen”, w: Robert Spaemann, Das Natürliche und das Vernünftige Essays zur Anthropologie (München Zürich: Piper, 1987), 37. 
kim spojrzeniu na ludzki byt ogarniamy jedynie jego stronę materialna, podlegającą determinizmom przyrodniczym, ale ona nie wyjaśnia tego, kim on jest (jest on wprawdzie częścią natury, ale ją przekracza i redukowanie go do takiego wymiaru oznaczałoby, że pozostawałby istotą niezrozumiała). Człowiek bowiem jako osoba wykazuje zdolność do autodeterminacji i samoprzekraczania swej natury. Sam zresztą stwierdza w swoim wewnętrznym doświadczeniu, że jest tego typu istota, czyli wolną i zdolną do samostanowienia (co pozwala mu przekraczać determinizmy przyrodnicze): postępuje $\mathrm{w}$ ten albo w inny sposób, bo tak chce, chociaż jest uwarunkowany biologicznie. Co więcej, człowiek odczytuje swe właściwe przeznaczenie, co ukazuje go jako istotę zmierzającą do celu ostatecznego, do bytowej pełni, czyli szczęścia, które może odnaleźć tylko w Bogu. Tymczasem przyroda nie czyni go takim bytem, czyli zdolnym do samoprzekraczania, transcendencji, ukierunkowania na wieczną egzystencję. Jakie zatem może być wytłumaczenie tego faktu? Nie może on wynikać z jego natury rozumianej przyrodniczo. Jeśli więc, jak podkreśla Spaemann, pytamy o tę kwestię, czyli o to, co człowiek jako istota działająca w sposób wolny czyni sama z siebie lub może (potrafi) i powinna czynić, to musimy mówić o tym, co Nieuwarunkowane ${ }^{42}$, czyli o Bycie Absolutnym, a zatem o tym, co jest czymś więcej niż człowiek. Dlatego, według stwierdzenia Spaemanna, u podstaw jedności obu tych perspektyw - metafizycznej i przyrodniczej ${ }^{43}$ - może być tylko uznanie Bytu Absolutnego jako celu człowieka i zarazem źródła jego natury. Jeżeli ktoś uważa to za niemożliwe do pomyślenia (wyobrażenia), wówczas dla dobra człowieczeństwa człowieka powinien przynajmniej zrezygnować z zamiaru przezwyciężenia dualizmu, czyli rozdwojonego (rozdartego) obrazu człowieka ${ }^{44}$. Lepiej bowiem, jeśli akceptuje dualizm, niż miałby przyjmować monizm. W ten bowiem sposób nie redukuje człowieka do jednego wymiaru, chociaż nie potrafi uzgodnić wykładni jedności wiedzy o nim. $W$ takim wypadku powinien on ciągle mieć na

42 Pod pojęciem Das Unbedingte, „To, co Nieuwarunkowane”, Spaemann ma na myśli Boga. Robert Spaemann, "Zamach na niedzielę", w: Granice. O etycznym wymiarze działania, przeł. Jarosław Merecki (Warszawa: Oficyna Naukowa, 2006), 473. Wyrażenie „To, co Nieuwarunkowane”, jak konstatuje prof. Berthold Wald z Paderborn, wprowadził Hegel. Jest to filozoficzne określenie Boga. („Das Unbedingte, ist so zu sagen, philosophische Name von Gott. Dieses Ausdruck hat Hegel eingeführt"). (Na podstawie wywiadu przeprowadzonego przez autora artykułu z prof. B. Waldem w czerwcu 2019 r.).

${ }_{43}$ Zdaniem prof. Walda przyrodoznawstwo, które nie wyklucza Boga, pozostawia przestrzeń dla metafizycznego poznania, gdyż nie twierdzi, że jego wykładnia wiedzy o człowieku stanowi jej całość. (Na podstawie wywiadu przeprowadzonego przez autora artykułu z prof. B. Waldem w czerwcu 2019 r.).

44 Spaemann, „Über den Begriff einer Natur des Menschen”, 38. 
uwadze to, co Friedrich Schiller zalecał w swojej epoce badaczom przyrody i filozofom:

Wrogość niech będzie między wami,

Na sojusz jest jeszcze za wcześnie.

Prawda zostanie poznana dopiero wtedy,

Kiedy będziecie się między sobą różnićt ${ }^{5}$.

\section{Bibliografia}

Horkheimer Max. 1970. Die Sehnsucht nach ganz Anderen. Hamburg: Furche-Verlag.

Kożuchowski Józef. 2013. O człowieku i moralności w filozofii Roberta Spaemanna. Lublin: Towarzystwo Naukowe KUL.

Plessner Helmut. 1981. „Die Stufen des Organischen und der Mensch. Einleitung in die philosophische Anthropologie". W: Gesammelte Schriften. Bd. IV. Frankfurt am Main: Suhrkamp.

Spaemann Robert. 2007. Das unsterbliche Gerücht. Stuttgart: Klett-Cotta. Spaemann Robert. 2007. Der letzte Gottesbeweis. München: Pattloch.

Spaemann Robert. 2012. „Die zwei Interessen der Vernunft”. W: Robert Speamann. Über Gott und die Welt. Suttgart: Klett-Cotta.

Spaemann Robert. 2006. „Kto i za co jest odpowiedzialny”. W: Robert Speamann. Granice. O etycznym wymiarze działania, przeł. Jarosław Merecki. Warszawa: Oficyna Naukowa.

Spaemann Robert. 2006. „Nienawiść Sarastra”. W: Robert Speamann. Granice. O etycznym wymiarze działania, przeł. J. Merecki. Warszawa: Oficyna Naukowa.

Spaemann Robert. 2001. Osoby. O różnicy między czymś a kimś, przeł. Jarosław Merecki. Warszawa: Oficyna Naukowa.

Spaemann Robert. 2006. „Zamach na niedzielę”. W: Robert Speamann. Granice. O etycznym wymiarze działania, przeł. J. Merecki. Warszawa: Oficyna Naukowa.

Spaemann Robert. 1987. Über den Begriff einer Natur des Menschen. W: Robert Speamann. Das Natürliche und das Vernünftige Essays zur Anthropologie. München, Zürich: Piper.

Spaemann Robert. 2007. „Wirklichkeit als Anthropomorphismus”. W: Robert Speamann. Schritte über uns hinaus Gesammelte Reden und Aufsätze II. Stuttgart: Klett-Cotta.

Stępień Antoni B. 1995. Wstęp do filozofii. Lublin: Towarzystwo Naukowe KUL.

45 Za: Spaemann, „Über den Begriff einer Natur des Menschen”, 38. 


\section{Streszczenie}

$\mathrm{W}$ artykule przedstawiono dwa ściśle $\mathrm{z}$ sobą powiązane zagadnienia $\mathrm{w}$ ujęciu zmarłego w 2018 roku wybitnego filozofa niemieckiego Roberta Spaemanna. Pierwsze to charakterystyka dwóch redukcjonistycznych stanowisk: naturalizmu i spirytualizmu oraz płaszczyzn, na których w szczególny sposób się zaznaczają: nauki i filozofii, refleksji antropologicznej i moralnej. Drugie zagadnienie dotyczy ewentualnej perspektywy jedności wiedzy o człowieku w kontekście teorii tych stanowisk, a zwłaszcza jedności dwóch sposobów (perspektyw) poznania człowieka: przyrodniczego i metafizycznego.

Oczywiście z rozważań Spaemanna nad naturalizmem i spirytualizmem przebija jego krytyczny stosunek do tych doktryn. Są one zawsze uwikłane w błędne interpretacje i ujęcia oraz sprzeczności (ambiwalencje), a nawet dogmatyzm. Spaemann pokazuje to w kilku różnych kontekstach: współczesnej nauki i filozofii, teorii znanych uczonych i filozofów oraz na przykładzie ważkich zjawisk z zakresu problematyki antropologicznej, moralnej i eko-filozoficznej.

Tezy antropologiczne formułowane przez naturalizm i spirytualizm, jako przeciwstawne sobie, nie dają się ze sobą pogodzić i w tym sensie nie pozwalają uzyskać jedności wiedzy o człowieku. Możliwa jest natomiast, zdaniem Spaemanna, jedność dwóch sposobów poznania człowieka: przyrodniczego i metafizycznego.

Godne podkreślenia są oryginalne i interesujące wątki Spaemannowskich analiz. Do nich z pewnością należy zaliczyć identyfikację elementów spirytualistycznych w teorii Singera i Dennetta oraz w mentalności współczesnego człowieka.

Dodajmy, że Spaemann problemu zarysowanego w tym artykule nie rozważał wprost w żadnym ze swych pism. W artykule zatem została podjęta próba jego opracowania przez uwzględnienie całokształtu dorobku naukowego monachijskiego myśliciela.

Słowa kluczowe: filozofia, dualizm, naturalizm, spirytualizm, jedność, wiedza

\section{Summary}

\section{Naturalism, Spiritualism and the Problem of the Unity of Knowledge about Man: Robert Spaemann's Position}

The article presents two issues closely related to each other in relation to the eminent German philosopher, R. Spaemann, who died in 2018. The first one describes the characteristics of two reductionist positions, naturalism and spiritualism, and how they stand out in a special way based on science and philosophy, including anthropological and moral reflection. The second issue concerns the possible perspective of the unity of knowledge about man in the context of the theory of these positions, and especially the unity of two ways (perspectives) of learning about man: the natural and the metaphysical. 
Of course, Spaemann's reflections on naturalism and spiritualism pierce his critical attitude towards these doctrines. They are always entangled in misinterpretations, approaches and contradictions (ambivalences), and even dogmatism. Spaemann shows this in several different contexts: modern science and philosophy, in the theories of known scientists and philosophers, based on the example of important phenomena in the fields of anthropological, moral, and eco-philosophical issues.

Anthropological theses formulated by naturalism and spiritualism are in contradiction and cannot be reconciled with each other, and in this sense, they do not allow for the unity of knowledge about man. According to Spaemann, it is possible, however, to unite two ways of getting to know about man: the natural and the metaphysical.

The original and interesting threads of Spaemann's analyses are worth emphasizing. These certainly include identifying spiritual elements in Singer and Dennet's theory and in modern man's mentality.

Let us add that Spaemann did not directly consider the problem outlined in this article in any of his writings. Therefore, the article attempts to develop this by taking into account the Munich thinker's overall scientific output.

Keywords: philosophy, dualism, naturalism, spiritualism, unity, knowledge 